\title{
FOOD FOR THOUGHT: AMA ATA AIDOO'S GASTRO-POLITICS
}

\author{
Violetta Jojo Verge \\ Universidad de La Laguna
}

\begin{abstract}
Some of Ama Ata Aidoo's short stories in her collections The Girl Who Can And Other Stories, and Diplomatic Pounds, deal with arguments over food and cooking. These trivial quarrels become food for thought. The aim of this research is to unveil the post and neocolonial tensions that are created during the re-encounter of peoples of African origin coming from different places and, consequently, different cultures. This paper adopts the idea of "gastro-politics" developed by Arjun Appadurai, who believes that the elaboration of the cuisine and its socio-economic context builds up the capacity of food to convey social messages. The bone of contention among Aidoo's characters is the food they are about to prepare, eat or sometimes never taste.
\end{abstract}

KeYwords: Gastro-politics, the exotic, African cuisine, nation-building, pan-Africanism, global village.

\author{
LA GASTROPOLÍTICA \\ EN CUENTOS DE AMA ATA AIDOO
}

\section{RESUMEN}

Los cuentos cortos de Ama Ata Aidoo en sus colecciones The Girl Who Can And Other Stories y Diplomatic Pounds, nos permiten conocer personajes que riñen por la comida y por cómo cocinarla. Estas disputas triviales son materia de reflexión. El objetivo de esta investigación es desvelar las tensiones pos- y neocoloniales que se crean durante el reencuentro de gentes de origen africano común, de diferentes países y culturas. Este estudio adopta la idea de la «gastropolítica» elaborada por Arjun Appadurai, que cree que la elaboración de la cocina y su contexto socio-económico dotan a la comida de la capacidad de transmitir mensajes sociales. El elemento de discordia entre los personajes de Aidoo es la comida que están a punto de preparar, comer o a veces nunca probar.

Palabras claves: Gastro-política, lo exótico, la cocina africana, construcción de la nación, pan-Africanismo, aldea global.

DOI: https://doi.org/10.25145/j.recaesin.2020.80.09

Revista Canaria de Estudios Ingleses, 80; April 2020, pp. 161-169; ISSN: e-2530-8335 
The Ghanaian author Ama Ata Aidoo has turned her writing to her advantage. Not only is she a committed writer in Molara Ogundipe-Leslie's sense, that is, "as a writer, as a woman, and as a Third World Person," (James 14) but also, as she explained in the same interview with Adeola James, she is a nationalist:

I don't deny that we belong to a larger, non-northern world and the dynamics that operate in a situation like that, but find my commitment as an African nationalist a little more pressing. It seems there are things relating to our world, as African people, which are of a more throbbing nature in an immediate sense. (James 15)

This nationalist writer deals with highly political issues through her easy-toread-short stories and tales about everyday life. Her hidden intention of questioning important topics about Africa and the Africans and their submission to invisible imperial power is surfaced through her irony. She challenges the concept of global village and puts it side by side with the binary opposition: First World versus Third World. She also prefers to use Kwame Nkrumah's term "neo-colonialism" to that of "post-colonialism". "Neo-colonialism", according to Ashcroft's Key Concepts in Post -Colonial Studies, refers to forms and ways of control of the ex-colonies after political independence. Both Aidoo and Nkrumah (the first president of the independent Ghana) use the term to make reference to the invisible superpowers that continued to play a decisive role in their cultures and economies through new instruments of indirect control that were still ruling after the independence of Ghana and other African countries (Ashcroft 162-163).

Aidoo's short story "Some Global News," dedicated to a New Yorker of Caribbean parentage, promulgates the importance of everyday issues such as clothes and food. The main topic in this tale is the problems the leading character Yaa-yaa Mensah, an important African woman, encounters regarding her clothes and what to wear when she travels abroad away from Africa. She is "struggling to deal with the idea of the global village" (73). She does not know where the idea came from and she wonders "whose village is it, anyway?" All these reflections are due to the fact that her African clothes always provoke the Europeans' or Americans' comments. The people in the congresses and meetings she goes to abroad always seem to find her clothes either inadequate for their cold weather, or too colourful or even exotic. Yaa-yaa ponders over the contradiction created when the global village cannot yet embrace the singularities of the different identities from other countries. She verifies through this type of experience that the global village still means the First World as the centre that imposes aesthetics, fashion and other important things, whereas the Third World's aesthetics is still pushed to the margins.

Yaa-yaa meets her best friend Kate to tell her about her worries and to share an African meal. It is the wise commentator's reflections on their African dish that triggered the idea of this paper. The meal they are about to eat, sitting on the carpet, is fufu with groundnut soup, a typical African dish that Aidoo's wise commentators could not let go unremarked: 
You mean peanut soup? Or rather, peanut broth? The colonizers made sure us people called some ordinary vegetables by different names. One wonders why... Maybe to help us maintain a little more of our primitiveness, however well we spoke their language? Or, and to make certain that we never really became that familiar with it? (80)

This wise commentator is not the common narrator. He is another invisible character that has full knowledge of their history, and his is a critical vision. Aidoo adopts this type of commentator from the Ghanaian theatrical tradition to achieve her criticism. He brings forward the problem of naming that the colonised countries suffered during the rule of the coloniser. Naming, in this case according to the commentator is due to the need to draw a differentiating line between the coloniser and the local Africans. Arjun Appadurai relies on anthropologists' works (as Firth, Geertz, and Young's, among others) to say in his article "Gastro-Politics in Hindu South Asia" (1981), that "Food, in its varied guises, contexts, and functions, can signal rank and rivalry, solidarity and community, identity or exclusion, and intimacy or distance" (494). Aidoo here highlights the distance created by the coloniser by presenting a new culinary and linguistic binary opposition of peanut broth versus groundnut soup. And thus, mimics more binary oppositions between:

- Coloniser / colonised

- Non-African / African

- Educated / primitive

- African Elite / common poor Africans

Aidoo must have experienced what Appadurai theorises on, thanks to her trips abroad. She wrote other short stories that deal with the topic of food. In an interview led by Maureen Eke, Vincent Odamtten, and Stephanie Newell, for the special number of African Literature Today 31 entitled Writing Africa in the Short Story, Odamtten suggested then that Margaret Atwood had said that writers don't deal with simple things we do, like eating, whereas in Aidoo's stories "food comes to play a part in the way the narrative moves" (164). He asked her what she thought of food in her stories and she answered "It's almost like a character" (164).

In "Nutty" the subject matter is also food. Aidoo again writes about gastropolitics defined by Appadurai as "conflict or competition over specific cultural or economic resources as it emerges in social transactions around food" (495). The narrator draws the readers' attention, from the first paragraph, to one of the bones of contention in this and other short stories "And did she say translate into English? American English, that's what's relevant to this story. Because of the confusion over 'groundnuts' and 'peanuts' (46). The problem is presented at the beginning when the question about the naming of this product is raised. The narrator inquires into the lack of an English name for groundnuts. He seems to know that "Quite likely, the early American settler in what came to be known as the South got that nut from their African slaves, and promptly called it peanut" (46). According to The Cambridge World History of Food, "Two other American crop introductions need 
to be mentioned. One is the groundnut [...] Groundnuts serve both as a food and cash crop for many Africans in the sub-humid and semiarid parts of the continent" (1335). In contrast, the French gave it the name Arachide. Another query is who called them groundnuts first? Then comes the nuisance of translating all the names of the African ingredients, such as Nkatse (groundnuts), and Akoko-Nkatenkwan (chicken groundnut stew or soup) into British English and American English. In addition to that, the uselessness of trying to explain how to prepare these dishes with what they perceive as strange ingredients.

"Nutty" is a story about an African young girl called Aku-Yaa who shared in North America an apartment with three other girls, one of them a Latin American and the other two white Americans. She and Blanche, one of the white Americans, became good friends. They had decided that each would cook a Sunday supper per month for both. Since their budget was low, Aku-Yaa thought that cooking an akoko-nkatenkwan would be a good idea because it is not expensive. But once AkuYaa served the rice with the groundnut stew prepared with chicken, ginger, onions and tomato sauce, Blanche tasted it as if she were taking poison. However, once she tasted it properly she even asked for more. This hurt Aku-Yaa so much that she never forgot the incident.

Fifteen years later, when Aku-Yaa goes to North America, she gets in touch with Blanche, as she normally does every time she visits. They usually have supper together in restaurants or at Aku-Yaa's hotel. But this time Blanche wanted to impress her African friend and prepared what she called "a new exotic recipe." Aku-Yaa was shocked when, among the four-course meal, she smelt the aroma of the nkatsekwanna-akokonam, which was the same chicken cooked in peanut butter or groundnut paste she had prepared years for her friend.

The twist in this tale underlines Appadurai's idea that "In general, food can be made to encode gastro-political messages by manipulating the food itself (in terms of quantity or quality) or by manipulating the context (either in terms of precedence or of degree of commensal exclusivity)" (501). In this text, Aidoo uses both concepts, the quantity and the quality of the food offered in this supper, to precipitate an emotional conflict between the two characters. Firstly, Blanche uses the adjective "exotic" to describe the dish she had prepared for her African friend. This ruffled Aku-Yaa's feathers: "A stone dropped into the pit of Aku-Yaa's belly. Just like that. Where did the stone come from? Aku-Yaa had no idea. An 'exotic dish'? She'd been travelling widely around the world, and long enough to know by now that these days the exotic means: strange weird, dumb" (50). Secondly, the fact of a four-course meal made her feel uncomfortable: "She was not going to allow herself to feel bad that where she came from, sometimes even a one-course meal was a problem for many to achieve" (51). Finally, Aku-Yaa served herself what smelt like the African Nkatsekwan-na-akokonam, that is, chicken done in peanut butter or groundnut paste. But after tasting it and liking it, she noticed that the ingredients and mode of preparation were not African: "This was American supermarket chicken cooked in bottled American peanut paste, smooth and creamy. Wonderful, but somehow different from the end-product at home, made from a combination of similar but slightly more natural ingredients" (52). 
Furthermore, when Aku-Yaa tried to remind Blanche that this was the same dish she had prepared for her fifteen years ago, the latter could not remember in spite of her terrible and disgusting reaction then. While they were discussing this matter, Aku-Yaa could hear a song by a popular highlife band that a radio station once classified as world music. Knowing that Highlife is a style of dance music created in West Africa, most probably in Ghana, the parallelism that Aidoo creates between the fate of the Nkatsekwan-na-akokonam (an African dish) and Highlife music (an African style of dance music) brings forward again the global village concept of rejecting the origin of these African consumer produce and gobbles them to unify a kind of what can be called universal, or better say in this case, American products: "This global village where African music is only part of 'world music', maybe African food becomes edible only when it is part of an exotic universal cuisine" (53). At this stage, Lévi-Strauss's three categories: the raw, the cooked and the rotten, presented in his work "The Culinary Triangle," are surpassed by the manipulated, long-life, American canned food as a sign of civilization and culture for the sake of universalising and creating a product for the global village. Hence, from the individual and group-specific ways of preparing food explained by Strauss, the processed and canned food is the means to guzzle individual identities and unify under the superpower.

In fact, "Nutty" is not the only short story that deals with the topic of food. Ama Ata Aidoo starts another short story, "About the Wedding Feast," with the following words: "With a little warning for all those who may be allergic to the genre: that this is "kitchen literature" with a vengeance"1 (87). She signed this paragraph with triple capital " $\mathrm{A}$ " in order to avoid any confusion regarding the source of these lines. Aidoo's "kitchen literature" does not conform to cookery books, but they talk about food. Igor Cusack stands by Catherine Palmer's affirmation that "food, along with landscape and the body, is an aspect of modern material world that is important to both individual and collective identities" (208). He believes food, and the manner in which the ingredients are mixed and prepared, is a significant constituent of a national identity. It is a consumable object of identity. It can expose human characteristics. We have seen in many occasions in history that it is food that forms the main part of aid to other countries or peoples under the effects of natural catastrophe or war. Appadurai also asserts that "The second fundamental fact about food, although this is much less well understood, is its capacity to mobilize strong emotions" (494).

This short story told by an African grandmother is about the preparations of her granddaughter's wedding in a foreign country. The bridegroom was also African though from a different country. The grandmother is complaining to her friends back home about the way things have changed when it comes to the topic of traditional marriage steps. If they had followed her African tradition, the granddaughter

1 "With a vengeance" is a phrase used to emphasize the degree to which something occurs or is true (energetically, vigorously, etc.). 
should have started by hinting to the mothers or women in her family and her community that she was thinking of getting married. Instead, she had announced it directly not having in mind any possibility of discussion with her mother Mary, or her grandmother. The storyteller continues with her complaints but this time it is about the procedures followed before the wedding feast. The grandmother does not understand why her daughter Mary and the boy's mother have to meet to discuss the preparation of the food for the wedding feast. Moreover, since the in-law family did not have any grandmothers coming to the meeting, our storyteller was invited to be present though she had to be silent. While the two mothers talked about the wedding cake and other deserts, everything went fine. They even discussed how to do the groundnuts and other things for the guests to munch on while waiting for the main dishes. But when they started talking about the main dishes, each wanted to impose her typical local dishes from each country. They argued, shouted and even stood up facing each other until the young couple arrived and laughed at them. They ended their meeting and decided not to meet until the wedding day. Each family prepared their own typical dishes and all the guests enjoyed eating all the food without complaining.

According to Appadurai's section "The Marriage Feast," in his article mentioned above, "the marriage feast is a quintessentially gastro-political arena" (502). Appadurai's observation about the South Asian marriage feasts can be applied to this African marriage feast: "Marriage feasts constitute a heavy drain on the resources of the bride's family; yet the lavishness and harmonious conduct of such feasts, and the maximization of the number of satisfied guests, are crucial determinants of the future status and reputation of the bride's family, as well as of the future strength or weakness of the affinal bond" (502). To start with, the storyteller is the grandmother who belongs to the eldest generation in this tale. She behaves like a watchdog for traditions. From the beginning the granddaughter does not announce her wedding in the traditional way, maybe because they are living abroad far from Africa. According to the grandmother, the boyfriend is also African, but not from their country. Another rule they break is that this marriage feast will be prepared by both families and not only the bride's family, in order to share the burden of buying and preparing all the food. Hence, the bride's family will not be the only people to be judged and their reputation will not suffer. Hence, if both families are going to share the economic and preparation responsibilities, where is the problem? According to the main premises of panAfricanism the African people both in Africa and the diaspora share the same history and fate. Their destiny is intertwined. The ideology rests on the idea of unity through solidarity and cooperation to achieve economic, social and political progress. Bringing together two African families to organise the feast and work together must be very easy. Having in mind that they are probably going to cook African food, they will all make use of a common African cuisine. Both mothers meet and start talking: "They had discussed everything in a friendly way: the wedding cake itself; other cakes; biscuits and buns; how to do the groundnuts and the other things for the guests to munch and crunch..." (89-90). As the story is told to the grandmother's people back home, Aidoo uses the invisible figure 
of what I called "the audience-within" in my $\mathrm{PhD}$ dissertation. ${ }^{2}$ The "audiencewithin" seems to be surprised and ask the grandmother about the groundnuts. She answers "Groundnuts? Oh, yes, they are everywhere! Except that in most places, they call them peanuts!" (90). This short story does not expound on the issue of groundnuts versus peanuts, but it rather seems to focus on the unexpected quarrel raised because of the African recipes when it came to what they called "real cooking" (90). Here we can see how food has the power to arouse strong emotions as Appadurai suggested. On the other hand, Igor Cusack affirms in his article "African Cuisines: Recipes for Nation- Building" that "The main driving force for the creation of national cuisines in Africa appears to come from the West, and in particular from African-American. There is considerable interest in African cuisine often treating the continent as a whole or in regions, a panAfrican cuisine" (216). The two mothers do not live up to Cusack's observation, because they dispute on the ingredients for the spinach stew. One would say that it was cooked with only onions and the other insisted that fish and meat had to be added. There was no consensus. When the wedding day arrived, the bride's family prepared the famous palava sauce of spinach with egusi, meat and fish, whereas the boy's mother prepared spinach stew without meat or fish. Each prepared her own recipes and the guests were as happy as can be. No one protested and all the food was eaten. The storyteller's reflection here is how people talk about change but they are not ready to handle these changes. In my opinion, Aidoo throws light on the difficulty of abiding by the premises of pan-Africanism, since what people might consider trivial things as national dishes cause such confrontations. The storyteller remembers her mother's statement "What is food anyway? Once it goes down the throat...” (92).

But I stand by Appadurai when he says that food "is a highly condensed social fact" (494). In 2012 Ama Ata Aidoo presented two more short stories in her new collection Diplomatic Pounds and Other Stories that can be analysed here to exemplify the last binary opposition proposed above: African elite versus common poor Africans. The main characters in "Diplomatic Pounds" are an African Ambassador's wife and her daughter Cecille. The life of a diplomatic couple is based on public relations and social activities, like going to many business lunches, dinners and cocktails. That is, food and more food everywhere. Their daughter had weight problems and was getting obsessed. She had scales everywhere in the huge house. Lady Ambassador did not eat and kept her diet. Cecille did not understand "What's the point of being in the diplomatic service if one isn't going to explore the food of other people" (34). They argued all the time on the topic of Cecille's overweight. The Lady's advice irritated the young girl, and she complained about her daughter's questions,

[W] hat life would be worth if everyone behaved like me [mother] and ate nothing at all? And then being Africans, and with so much hunger on our continent, wasn't

\footnotetext{
2 "The audience within" are the invisible listeners to a story telling moment or simply gossipers. For PhD dissertation see works cited.
} 
it sheer insensitive cheek that we had but would not eat because we didn't want to get fat? (34)

The idea of having to control their weight contrasts with the real news coming from African countries reporting the hunger that the common poor African people suffer from and their starvation. Food excess is the problem in this story. The ambassador and his family belong to the African elite, and this is highlighted, in addition to their diplomatic service, through their attitude towards food. No common poor African would reject food so as not to put on weight.

The story ends with a visit to the psychiatrist, who, according to the Ambassador Lady, was laughing at the girl's crazy stories about the scales not allowing her to go close to the kitchen. The mother was worried about the gossipers and reassures herself thinking "We are high class. In fact, our family is the highest. After all, who else among our people here in London a re ambassadorial retirees? Eh?" (37) The mother's last lines are "But Cecille has not gone crazy. She is just having a little nervous breakdown" (37). The elite worries about overweight caused by excess of food, whereas the poor worry about how to get their daily food to survive.

The two-page-short story "Recipe for A Stone Meal" was initially published in Flash Magazine in 2008. It is about an African woman who has to go to a refugee camp with her two children. After hours in a queue, a UN officer gives her some beans to cook. She cooks the beans all night but they are still hard as stones. Her child passes out and the doctor says that he is starving. She just cannot understand why she hasn't been able to soften the beans. The doctor explains that these beans were not the adequate ones for the little water and fire they had in the camp. The story ends with the doctor's biting criticism: "Those UN characters should have brought only the powdered lot here. But maybe they could not be bothered. Or they sent the bags of powdered meal to their relatives at home" (62). The mother faints as well. It is a story about starvation even when the common poor Africans are in refugee camps. There is this echo coming from different conflict zones in Africa where the aids that other countries send be it money, material for shelters or food never seem to get to the proposed final destinies. The problem here is political and Aidoo's story hits the UN officers' honesty with deadly arrows so that the rest of the world can read. Again, in this case, and as if standing by the previous short story, food seems to be one of Aidoo's main instruments to write and inform about, as well as criticise that society.

Finally, I believe that Aidoo has written in accordance to her own ideas and words when she explained in the mentioned interview that "It's not just the fact that I like food, or that food is vital element in any people's culture and in any individual's life. Since I started coming here [to the US] many years ago, I have been interested in the clash between African ways of doing things and specifically Western ways of regarding food" (165). 


\section{WORKS CITED}

Ardoo, Ama Ata. “Ama Ata Aidoo: An Interview for ALT.” An interview with Maureen Eke, Vincent Odamtten and Stephanie Newell. ALT 31: Writing Africa in the Short Story: African Literature Today, edited by Ernest N. Emenyonu et al., James Currey, 2013, pp. 162-168.

Aidoo, Ama Ata. "About the Wedding Feast." The Girl Who Can and Other Stories. Heinemann, 2002, pp. 87-92.

Ardoo, Ama Ata. "Diplomatic Pounds." Diplomatic Pounds and Other Stories. Ayebia Clarke Publishing Limited, 2012, pp. 33-37.

Aidoo, Ama Ata. Diplomatic Pounds and Other Stories. Ayebia Clarke Publishing Limited, 2012.

Aidoo, Ama Ata. "Nutty." The Girl Who Can and Other Stories. Heinemann, 2002, pp. 46-54.

Aınoo, Ama Ata. "Recipe for A Stone Meal." Diplomatic Pounds and Other Stories. Ayebia Clarke Publishing Limited, 2012, pp. 61-62.

Aidoo, Ama Ata. "Some Global News." The Girl Who Can and Other Stories. Heinemann, 2002, pp. 72-86.

Aidoo, Ama Ata. The Girl Who Can and Other Stories. Heinemann, 2002.

Appadurai, Arjun. "Gastro-Politics in Hindu South Asia." American Ethnologist, vol. 8, no. 3, Symbolism and Cognition, Aug. 1981, pp. 494-511.

Ashcroft, Bill, Gareth Griffith, and Helen Tiffin. Key Concepts in Post-Colonial Studies. Routledge. 1998, pp. 162-163.

CusAK, Igor. "African Cuisines: Recipes for Nation-building." Journal of African Studies, vol. 13, no. 2, Dec. 2000, pp. 207-225.

Emenyonu, Ernest N., et al., editors. ALT 31: Writing Africa in the Short Story: African Literature Today. James Currey, 2013.

Huggan, Graham. The Post-Colonial Exotic: Marketing the Margins. Routledge, 2001.

James, Adeola. In Their Own Voices: African Women Writers Talk. James Currey, 1990.

Jojo Verge, Violetta. The Re-Presentation of Africa and the African in the Anglophone West African Literature: Buchi Emecheta and Ama Ata Aidoo. 2015, U de La Laguna, PhD dissertation. https:// www.educacion.gob.es/teseo/imprimirFicheroTesis.do?idFichero=QuAgk3qAgG4\%3D.

Kiple, Kenneth F., and Kriemhild Coneè Ornelas, editors. The Cambridge World History of Food. Vol. 2. Cambridge UP, 2000.

LÉvi-Strauss, Claude. “The Culinary Triangle.” Food and Culture: A Reader, edited by Carole Counihan, Penny Van Esterik. Routledge, 2008, pp. 36-43. 
